\title{
Desain Sistem Informasi Akuntansi Berbasis Komputer untuk Penyusunan Laporan Keuangan Menggunakan Microsoft Access 2010
}

\author{
(Design of Accounting Information System Based on Computer for the \\ Preparation of Financial Statement Using Microsoft Access 2010)
}

\author{
Surya Sukmawan Sinatriyo*, Andriana, Kartika \\ Jurusan Akuntasi, Fakultas Ekonomi dan Bisnis, Universitas Jember (UNEJ) \\ Jln. Kalimantan 37, Jember 68121 \\ E-mail: surya.sinatriyo@outlook.co.id
}

\begin{abstract}
Abstrak
Penelitian ini bertujuan mendesain sistem informasi akuntansi berbasis komputer untuk penyusunan laporan keuangan menggunakan Microsoft Access 2010 pada perusahaan jasa pemasangan jaringan dan CCTV serta perdagangan komponenkomponen komputer, yaitu CV. Satria Computindo. Penelitian ini menggunakan pendekatan metode deskriptif kualitatif. Metode pengumpulan data dilakukan dengan cara wawancara dan dokumentasi, dan pengujian keabsahan data yang digunakan berupa triangulasi sumber, triangulasi waktu, dan membercheck. Sistem informasi akuntansi yang dimiliki antara lain sistim penjualan barang, sistem informasi pembelian barang, sistem informasi akuntansi penerimaan kas, sistem informasi akuntansi pengeluaran kas, dan sistem informasi akuntansi penggajian dan pengupahan.Desain sistem informasi akuntansi berbasis komputer untuk mendukung penyusunan laporan keuangan menggunakan teknik Rapid Application Development (RAD) yang mengembangkan sistem dalam periode yang singkat dengan menggunakan prototyping. Aplikasi yang digunakan untuk pengembangan sistem yaitu menggunakan Microsoft Access yang meliputi desain tabel, pembuatan relasi antar tabel, desain query, desain form, dan desain report. Penelitian ini diharapkan akan mengurangi terjadinya kesalahan pencatatan yang diakibatkan oleh faktor manusia, mempercepat perolehan informasi keuangan bagi Pimpinan serta mempercepat perolehan informasi stok barang secara real time.
\end{abstract}

Kata kunci: Laporan Keuangan, Microsoft Access 2010, Prototyping, Rapid Application Development - RAD, Sistem Informasi Akuntansi.

\begin{abstract}
This study aims to design a computer-based accounting information system for the preparation of financial statements using Microsoft Access 2010 on the small medium companythat provide network, cctv installation services and also trading computer components namely CV. Satria Computindo. This research used descriptive qualtitative. Methods of data collection is done by interview and documentation, and testing the validity of data used in the form of source triangulation, time triangulation, and membercheck. Accounting system used were selling, cash receiveing and cash disburshment and sallary and payroll accounting system. Design of computer-based accounting information systems to support the preparation of financial statements using Rapid Application Development (RAD) techniques that develop the system in a short period of time using prototyping. Applications used for system development is using Microsoft Access which includes table design, creation of relations between tables, query design, form design, and report design. This study is expected to reduce the occurrence of recording errors caused by human factors, accelerate the acquisition of financial information for the leadership and accelerate the real time acquisition of stock information.
\end{abstract}

Keywords: Accounting Information System, Financial Statements, Microsoft Access 2010, Prototyping, Rapid Application Development - RAD.

\section{Pendahuluan}

Perkembangan teknologi informasi pada sektor bisnis mempengaruhi perkembangan dan kemajuan akuntansi.

Kemajuan teknologi informasi mempengaruhi pengembangan desain sistem informasi akuntansi pada sektor bisnis. Teknologi informasi mampu meningkatkan kinerja pada sistem informasi akuntansi. Pemanfaatan teknologi informasi pada sistem informasi akuntansi dapat mempengaruhi strategi entitas bisnis dan dapat menjadi keunggulan kompetitif bagi entitas bisnis (Romney \& Steinbart, 2012:31).

Salah satu cara agar organisasi bisnis mampu bersaing dengan para kompetitornya adalah dengan menggunakan sistem informasi akuntansi dalam operasional perusahaannya. Sistem informasi akuntansi berkaitan dengan kemampuan entitas bisnis dalam pengambilan keputusan, penciptaan nilai rantai (value chain), penciptaan nilai tambah (value added) dan perencanaan strategi bisnis sedangkan pemanfaatan teknologi dapat meningkatkan kinerja dari sistem informasi akuntansi (Romney \& Steinbart, 2012:40).

Beberapa penggunaan sistem informasi akuntansi pada organisasi bisnis diantaranya adalah dengan menggunakan komputer atau yang biasa disebut dengan sistem informasi akuntansi berbasis komputer. Pemrosesan informasi pada sistem informasi akuntansi berbasis komputer hingga saat ini sudah banyak digunakan dengan software akuntansi yang dapat digunakan sebagai pengolah data untuk menghasilkan informasi dengan kelebihan akan memberikan manfaat lebih seperti seperti mempercepat pengolahan data, kecepatan proses yang lebih tinggi serta menghasilkan laporan

\footnotetext{
* Corresponding author
} 
keuangan yang sederhana dan real time bagi pemilik dan juga penyimpanan data yang ringkas dan aman, karena penggunaan software akan berjalan secara otomatis yang mempermudah pengguna yang kurang mahir dalam akuntansi.

Penggunaan Microsoft Access menjadi salah satu pilihan aplikasi yang dapat diimplementasikan oleh organisasi bisnis kecil dan menegah. Microsoft Access adalah aplikasi manajemen basis data relasional. Microsoft Access merupakan salah satu produk Microsoft Office yang dibuat oleh Microsoft Corporation. Salah satu kelebihan dari Microsoft Access yaitu aplikasi basis data yang dapat disesuaikan dan dikembangkan sesuai dengan kebutuhan secara cepat (Rapid Application Development - RAD). Microsoft Access memberikan keleluasaan bagi pengguna untuk mengembangkan tabel basis data, query, formulir, dan laporan sesuai dengan keinginan secara cepat (Widodo, 2014).

Pengaplikasian sistem informasi akuntansi dalam organisasi bisnis kecil dan menegah sangat berguna untuk operasional perusahaan, Namun pada kenyataannya tidak semua organisasi bisnis kecil dan menengah memanfaatkan sistem informasi akuntansi dalam kegiatan bisnisnya. Salah satunya adalah CV. Satria Computindo yang berlokasi di Jalan Basuki Rahmat No. 62 Ambulu, Jember yang berdiri sejak tahun 2015 dan mempunyai bidang usaha instalasi serta penjualan hardware, software, serta jasa pemasangan jaringan dan CCTV dan melayani pelanggan dalam wilayah Jember.

Rumusan masalah dalam penelitian ini yaitu bagaimana prosedur sistem informasi akuntansi yang ada pada CV. Satria Computindo dan bagaimana desain sistem informasi akuntansi berbasis komputer menggunakan Microsoft Access 2010 untuk pembuatan laporan keuangan pada CV. Satria Computindo. Sementara tujuan penelitian ini adalah utnuk mengetahui prosedur sistem informasi akuntansi yang selama ini digunakan oleh CV. Satria Computindo dan untuk mendesain sistem informasi akuntansi dengan berbasis komputer untuk pembuatan laporan keuangan menggunakan Microsoft Access 2010.

\section{Metode}

\section{Rancangan atau Desain Penelitian}

Penulis menggunakan jenis penelitian deskriptif kualitatif. Penelitian kualitatif atau paradigma kualitatif merupakan paradigma penelitian yang menekankan pada pemahaman mengenai msalah-masalah dalam kehidupan sosial berdasarkan kondisi realitas atau natural setiting yang holistis, kompleks, dan rinci (Indriantoro dan Supomo, 2015:12). Dalam penelitian ini yang menjadi subjek penelitian adalah CV. Satria Computindo, sementara ayng menjadi objek penelitian yaitu desain sistem informasi akuntansii menggunakan Microsoft Access 2010.

\section{Jenis dan Sumber Data}

Jenis data yang digunakan dalam penelitian ini adalah data primer dan data sekunder. Data primer merupakan data sumber data penelitian yang diperoleh secara langsung dari sumber asli, (tidak melalui perantara). Sedangkan data sekunder adalah dalah sumber data penelitian yang diperoleh peneliti secara tidak langsung melalui media perantara (diperoleh dan dicatat oleh pihak lain). Data sekunder umumnya berupa bukti, catatan atau laporan historis yang telah tersusun dalam arsip yang dipublikasikan dan yang tidak dipublikasikan (Indriantoro dan Supomo, 2014:147). Data sekunder dalam penelitian ini diperoleh dari wawancara dengan pemilik dan bagian Administrasi dan Keuangan, sedangkan data sekunder diperoleh dari catatan transaksi keuangan perusahaan,

\section{Metode Analisis Data}

Analisis data yang dilakuakan dengan mengikuti model analisis data Miles dan Hubermen, yang terdiri dari reduksi data (data reduction), penyajian data (data display), dan penarikan kesimpulan (conclusion drawing/verification). Hal ini dimaksudkan agar hasil penelitian ini dapat lebih tepat sasaran dan handal untuk diterapkan dalam aktivitas operasional CV. Satria Computindo.

Pengujian keabsahan data dalam metode penelitian kualitatif meliputi validitas internal (kredibiitas/credibility) pada aspek nilai kebenaran, pada penerapannya ditinjau dari validitas eksternal (transferability), dan realibilitas (dependeability) pada aspek konsistensi, serta objektivitas (confimatibility) pada aspek naturalis (Sugiyono, 2012). Pada penelitian kualitatif, tingkat keabsahan lebih ditekankan pada data yang diperoleh. Melihat hal tersebut maka kepercayaan data hasil penelitian dapat dikatakan memiliki pengaruh signifikan terhadap keberhasilan sebuah penelitian.

Berdasarkan empat jenis pengujian keabsahan tersebut, penelitian ini menggunakan uji kredibilitas. Menurut Sugiyono (2012), macam-macam uni kredibilitas dilakukan dengan cara perpanjangan pengamatan, meningkatkan ketekunan, triangulasi (triangulasi sumber, triangulasi teknik, triangulasi waktu), analisis kasus negatif, menggunakan bahan referensi, dan menggunakan membercheck. Uji kredibilitas pada penelitian ini dilakukan dengan cara triangulasi sumber, triangulasi waktu, dan membercheck. Hal ini disesuaikan dengan teknik pengumpulan data pada penelitian ini, yaitu wawancara dan dokumentasi.

Triangulasi sumber yaitu menguji kredibilitas data dilakukan dengan cara mengecek data yang telah diperoleh melalui beberapa sumber. Data yang diperoleh kemudian dideskripsikan dan dikategorisasikan sesuai dengan apa yang diperoleh dari berbagai sumber tersebut. Peneliti akan melakukan pemilahan data yang sama dan data yang berbeda untuk dianalisis lebih lanjut. Pada penelitian ini data diperoleh dari berbagai sumber seperti Pemilik perusahaan, dan bagian Administrasi dan Keuangan.

Triangulasi waktu yaitu narasumber yang ditemui pada pertemuan awal dapat memberikan informasi yang berbeda pada pertemuan selanjutnya. Oleh karena itu, perlu dilakukan pengecekan berulang-ulang agar ditemukan kepastian data yang lebih kredibel. Pada penelitian ini, peneliti melakukan beberapa kali pengecekan data pada objek penelitian di waktu-waktu yang berlainan.

Membercheck yaitu Proses pengecekan data yang diperoleh peneliti kepada pemberi data. Ini bertujuan untuk mengetahui seberapa jauh data yang diperoleh sesuai dengan apa yang diberikan oleh pemberi data atau informan. Apabila data yang ditemukan disepakati oleh para pemberi data berarti data tersebut valid. Pelaksanaan membercheck dapat dilakukan 
setelah satu periode pengumpulan data selesai, atau mendapat suatu temuan, atau kesimpulan. Proses membercheck pada penelitian ini dilakukan setelah peneliti mendapatkan suatu kesimpulan atas penelitian yang dilakukan.

\section{Hasil dan Pembahasan}

CV. Satria Computindo adalah sebuah badan usaha milik swasta yang bergerak di bidang teknologi yaitu teknologi informasi, teknologi jaringan, teknologi kelistrikan dan teknologi elektronika. Perusahaan yang berdiri sejak 2004 ini pada mulanya belum berupa badan usaha, hanya sebatas identitas sebuah toko yang bergerak di bidang jasa instalasi, maintenance dan jual beli perangkat komputer.

\section{Hasil}

Pada CV. Satria Computindo sistem informasi akuntansi yang berjalan adalah sistem informasi akuntansi penjualan barang, sistem informasi pembelian barang, sistem informasi akuntansi penerimaan kas, sistem infomrasi akuntansi pengeluaran kas, dan sistem informasi akuntansi penggajian dan pengupahan. Bagian-bagian yang terkait dengan sistem informasi akuntansi ini adalah pemilik usaha, yang memliki tugas secara umum yaitu pengarahan pada kegiatan yang telah direncanakan dengan perintah, instruksi dan masukan kepada bawahan untuk mencapai tujuan perusahaan; bagian pemasaran yang memiliki tugas untuk menawarkan prodeuk jasa dan barang, serta melayani pembeli di toko; bagian administrasi dan keuangan yang memiliki tugas membuat laporan keuangan dan mencatat semua transaksi-transaksi keuangan; dan bagian teknisi bertugas dalam mengerjakan pemsangan CCTV, hardware dan perangkat jaringan.

\section{Sistem Informasi Akuntansi pada CV. Satria Computindo}

Pada sistem informasi akuntansi penjualan barang prosedurnya yaitu karyawan menerima kepada bagian Administrasi dan Keuangan. Bagian ini menerima uang serta membuat nota penjualan yang terdiri dari dua rangkap sesuai. Rangkap pertama diserahkan pelanggan sedangkan rangkap kedua diserahkan ke bagian Administrasi dan Keuangan sebagai bukti dokumen untuk mencatat penjualan pada buku catatan, kemudian dokumen disimpan untuk dijadikan sebagai arsip oleh bagian Administrasi dan Keuangan.

Sistem informasi akuntansi pembelian barang prosedurnya yaitu pembelian barang dimaksudkan untuk penambahan stok barang yang ada. Sistem informasi akuntansi pembelian barang dimulai dari bagian Administrasi dan Keuangan melakukan pengecekan barang yang telah berkurang jumlahnya karena penjualan, rusak ataupun hilang. Bagian ini kemudian mencatat dan membuat daftar barang yang akan dibeli. Berdasarkan daftar ini, kemudian dibuatkan surat pembelian barang sebanyak dua rangkap. Bagian Administrasi dan Keuangan kemudian meminta persetujuan kepada Pimpinan. Jika surat pembelian barang tersebut tidak disetujui, maka pembelian barang dibatalkan. Jika surat pembelian barang tersebut disetujui, rangkap pertama dokumen tersebut dijadikan bukti dan arsip untuk mencatat pembelian barang pada buku catatan. Sedangkan rangkap kedua dikirimkan atau diberikan oleh bagian Administrasi dan Keuangan kepada pemasok barang. Jika barang yang dibeli tidak ada pada pemasok, maka bagian Administrasi dan Keuangan membuat kembali surat pembelian barang untuk pemasok lainnya.

Sistem informasi akuntansi penerimaan kas prosedurnya yaitu sistem informasi akuntansi dimulai dari pelanggan atau klien meminta jasa pemasangan CCTV atau jaringan kepada pemilik atau bagian Administrasi dan Keuangan secara lisan. Atas permintaan pelanggan tersebut, maka perusahaan segera membuat proposal dan menawarkan proposal sesuai dengan permintaan tersebut kepada klien. Jika proposal tersebut disetujui oleh klien, maka proposal tersebut ditanda tangani oleh kedua belah pihak sebagai tanda kesepakatan pengerjaan proyek, dan klien membayar uang muka pengerjaan proyek sesuai kesepakatan. Perusahaan mulai mengerjakan proyek setelah pembayaran uang muka diterima. Setelah proyek selesai dikerjakan, perusahaan meminta pelunasan proyek kepada klien. Klien kemudian membayarkan pelunasan atas proyek. Pelunasan proyek dan uang muka proyek kemudian dicatat sebagai pendapatan dalam buku catatan. Dokumen proposal kemudian disimpan sebagai arsip di perusahaan.

Sistem informasi akuntansi pengeluaran kas prosedurnya yaitu dimulai dari bagian Administrasi dan Keuangan mengeluarkan uang untuk membayar biaya operasional dan biaya umum kepada instansi terkait, kemudian mendapatkan bukti pembayaran sebagai tanda bukti telah melakukan pembayaran. Dokumen ini kemudian disimpan dan dijadikan arsip sebagai dasar untuk mencatat biaya-biaya pada buku catatan Pengeluaran kas dimaksudkan untuk pembayaran biaya operasional dan biaya umum, seperti biaya listrik, biaya internet dan sebagainya.

Sistem informasi akuntansi penggajian dan pengupahan prosedurnya dimulai dari bagian Administrasi dan Keuangan mengeluarkan uang untuk membayar biaya operasional dan biaya umum kepada instansi terkait, kemudian mendapatkan bukti pembayaran sebagai tanda bukti telah melakukan pembayaran. Dokumen ini kemudian disimpan dan dijadikan arsip sebagai dasar untuk mencatat biaya-biaya pada buku catatan. Pengeluaran kas dimaksudkan untuk pembayaran biaya operasional dan biaya umum, seperti biaya listrik, biaya internet dan sebagainya.

\section{Pembahasan}

Diagram Alir Data (Data Flow Diagram - DFD) Sistem Informasi Akuntansi CV. Satria Computindo

Diagram alir data menjelaskan proses atau arus data pada suatu organisasi secara grafis dalam bentuk diagram-diagram. Berdasarkan penelitian yang dilakukan pada CV. Satria Computindo penggambaran sistem yang berjalan saat ini menggunkan DFD ditunjukkan dengan diagram konteks, DFD level 0, dan DFD level 1.

Diagram konteks menggambarkan sistem secara umum. Entitas yang terlibat dalam sistem yaitu bagian Administrasi dan Keuangan dan Pemilik. Bagian Administrasi dan Keuangan meng-input data-data dan memprosesnya dalam sistem informasi akuntansi sehingga menghasilkan output berupa laporan yang ditujukan kepada pemilik. 


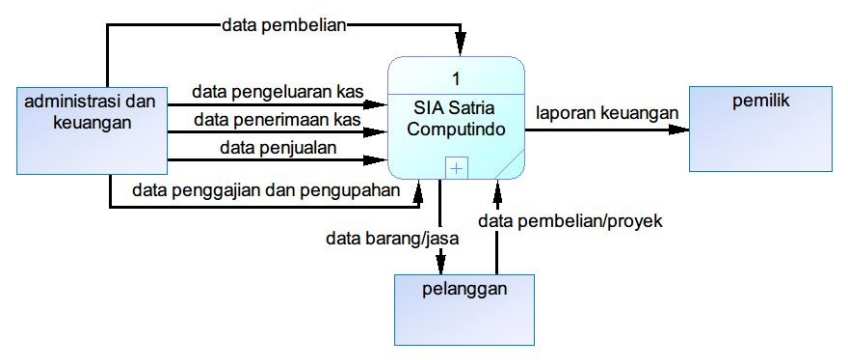

Gambar 1. Diagram Konteks

DFD Level 0 merupakan model dekomposisi atau penjabaran proses yang lebih rinci dari diagram konteks. Dalam sistem informasi akuntansi CV. Satria Computindo terdokumentasi delapan proses, yaitu proses beli barang, penerimaan kas, cek barang, pembelian barang, pengeluaran kas, penggajian dan pengupahan, serta pelaporan.

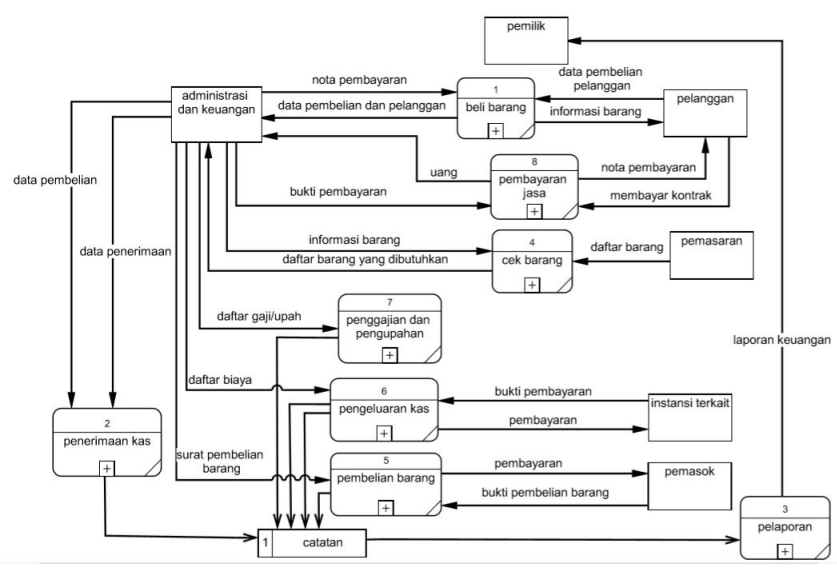

Gambar 2. DFD Level 0

DFD Level 1 merupakan model dekomposisi atau penjabaran proses yang lebih rinci dari DFD Level 0. Pada level ini, delapan proses hasil dari dekomposisi dari diagram konteks sistem informasi akuntansi CV. Satria Computindo akan di dekomposisi lagi menjadi proses-proses yang lebih rinci.

Pada DFD Level 1 Beli Barang ini akan dijelaskan prosesproses yang terjadi ketika pelanggan melakukan pembelian barang dan data-data apa saja yang disimpan.

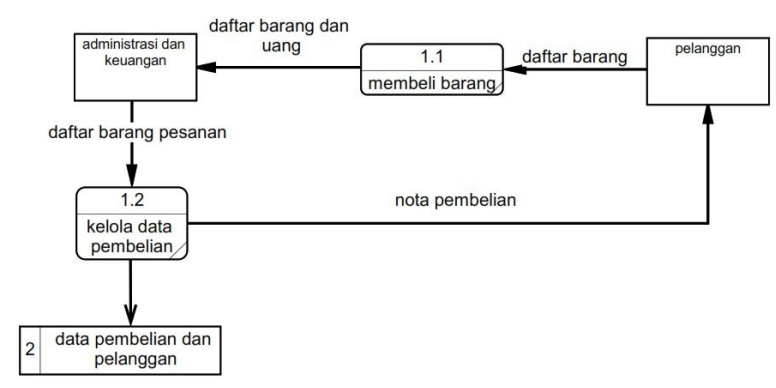

Gambar 3. DFD Level 1 Beli Barang

DFD Level 1 Beli Barang mempunyai proses-proses yaitu Proses 1.1 Membeli Barang, merupakan pelanggan memberikan daftar barang yang akan dibeli dan kemudian uang pembayaran kepada Bagian Administrasi dan Keuangan, dan Proses 1.2 Kelola Data Pembelian, merupakan bagian Administrasi dan Keuangan memproses daftar barang pesanan, dan menyerahkan nota pembelian kepada pelanggan. Data pesanan dan pelanggan disimpan dalam catatan yang nantinya akan menghasilkan laporan keuangan.

Pada DFD Level 1 Penerimaan Kas ini akan dijelaskan proses-proses yang terjadi ketika bagian Administrasi dan Keuangan melakukan penerimaan kas dan data-data apa saja yang disimpan.

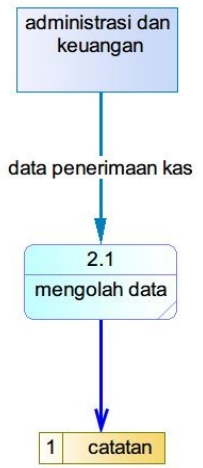

Gambar 4. DFD Level 1 Penerimaan Kas

DFD Level 1 Penerimaan Kas mempunyai proses 2.1 Mengolah Data, yaitu Bagian Administrasi dan Keuangan mengolah data penerimaan kas, kemudian data tersebut akan disimpan dengan bentuk pencatatan.

Pada DFD Level 1 Pelaporan ini akan dijelaskan prosesproses yang terjadi ketika karyawan melakukan pengecekan barang untuk stok dan data-data apa saja yang disimpan.

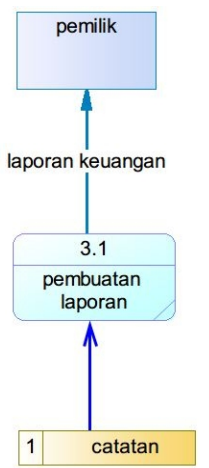

Gambar 5. DFD Level 1 Pelaporan

DFD Level 1 Pelaporan mempunyai proses yaitu 3.1 Pembuatan Laporan, pencatatan-pencatatan dari semua transaksi diolah menjadi laporan keuangan yang nantinya akan diberikan kepada pemilik usaha.

Pada DFD Level 1 Cek barang ini akan dijelaskan prosesproses yang terjadi ketika karyawan melakukan pengecekan barang untuk stok dan data-data apa saja yang disimpan.

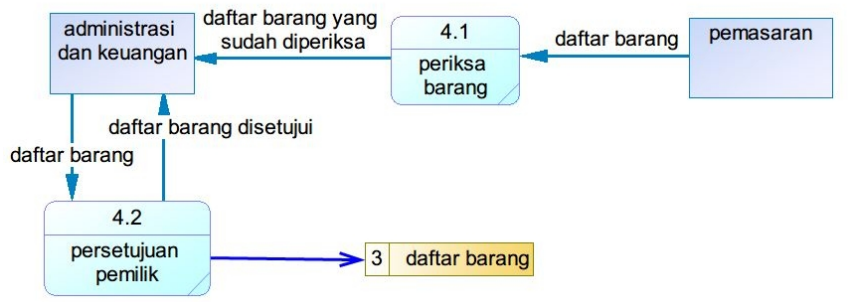

Gambar 6. DFD Level 1 Cek Barang 
DFD Level 1 Cek Barang mempunyai proses-proses yaitu Proses 4.1 Periksa Barang, merupakan dengan daftar barang yang ada, karyawan memeriksa barang untuk mengecek persediaan barang. Daftar barang yang sudah dicek/diperiksa kemudian diberikan kepada Bagian Administrasi dan Keuangan, dan Proses 4.2 Persetujuan Pemilik, merupakan Daftar barang yang sudah diperiksa kemudian dimintakan persetujuan kepada Pemilik. Daftar barang tersebut kemudian disimpan sebagai data daftar barang.

Pada DFD Level 1 Pembelian Barang ini akan dijelaskan proses-proses yang terjadi ketika pembelian barang yang dilakukan untuk stok barang di toko dan data-data apa saja yang disimpann.

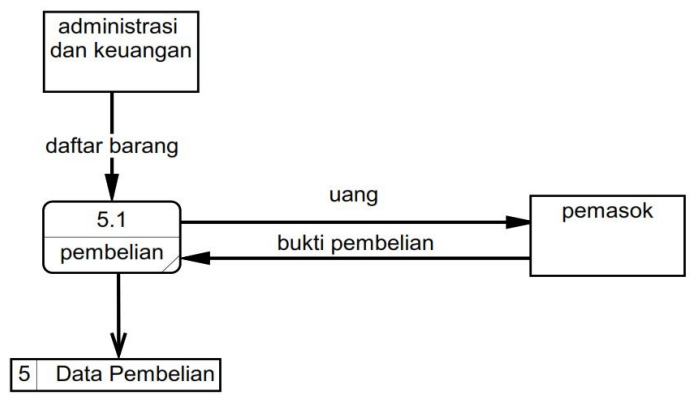

Gambar 7. DFD Level 1 Pembelian Barang

DFD Level 1 Pembelian Barang mempunyai proses 5.1 Pembelian yaitu Bagian Administrasi dan Keuangan melakukan pembelian berdasarkan daftar barang yang ada. Uang diberikan kepada pemasok atas pembelian barang yang telah dilakukan. Pemasok memberikan bukti pembelian. Bukti pembelian disimpan sebagai data pembelian.

Pada DFD Level 1 Pengeluaran Kas ini akan dijelaskan proses-proses yang terjadi ketika CV. Satria Computindo mengeluarkan uang untuk membayar biaya-biaya kepada instansi terkait dan data-data apa saja yang disimpan.

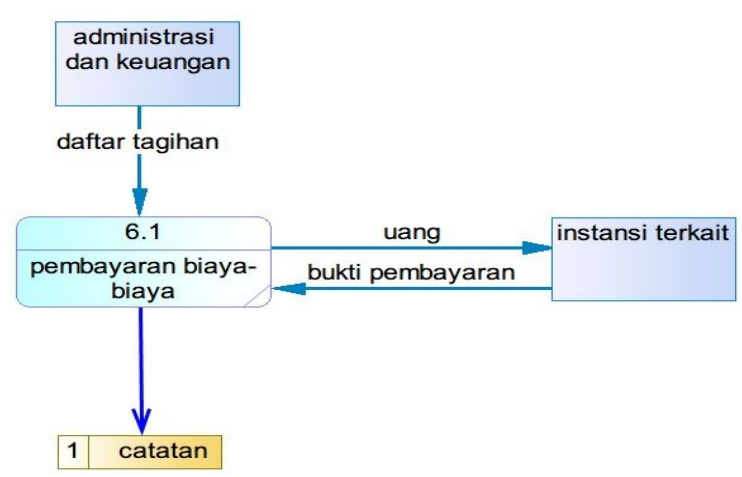

Gambar 8. DFD Level 1 Pengeluaran Kas

DFD Level 1 Pengeluaran Barang mempunyai proses 6.1 Pembayaran Biaya-Biaya yaitu bagian Administrasi dan Keuangan melakukan pembayaran biaya-biaya berdasarkan daftar tagihan yang ada. Uang diberikan kepada instansi terkait atas biaya-biaya yang telah terjadi. Instansi terkait memberikan bukti pembayaran. Bukti pembayaran disimpan sebagai pencatatan beban

Pada DFD Level 1 Penggajian dan Pengupahan ini akan dijelaskan proses-proses penggajian dan pengupahan kepada karyawan CV. Satria Computindo dan data-data apa saja yang disimpan .

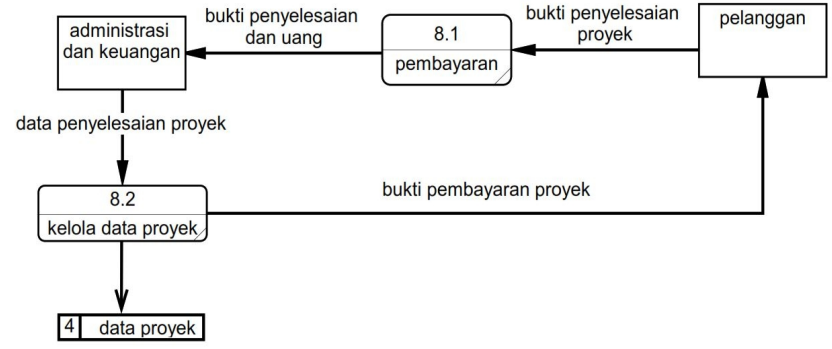

Gambar 9. DFD Level 1 Penggajian dan Pengupahan

DFD Level 1 Penggajian dan Pengupahan mempunyai proses 7.1 Pembayaran Gaji dan Upah, yaitu bagian Administrasi dan Keuangan menyiapkan daftar gaji dan upah sebagai dasar untuk membayarkan gaji dan upah untuk karyawan. Datadata daftar gaji dan upah kemudian disimpan dalam bentuk pencatatan.

Pada DFD Level 1 Pembayaran Jasa ini akan dijelaskan proses-proses pembayaran oleh pelanggan kepada CV. Satria Computindo atas jasa yang telah diselesaikan dan data-data apa saja yang disimpan.

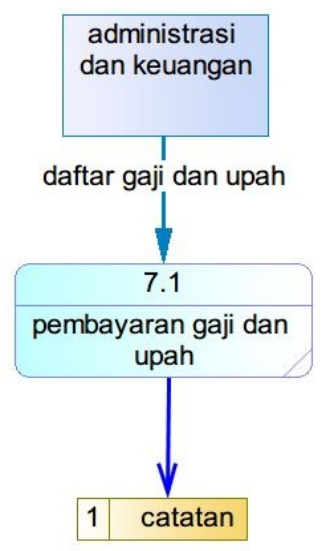

Gambar 10. DFD Level 1 Pembayaran Jasa

DFD Level 1 Pembayaran Jasa mempunyai proses-proses yaitu proses 8.1 Pembayaran, merupakan pelanggan memberikan bukti penyelesaian proyek untuk pembayaran. Uang serta bukti penyelesaian proyek kemudian diberikan kepada bagian Administrasi dan keuangan, dan proses 8.2 Kelola Data Proyek, merupakan bagian Administrasi dan keuangan memproses data penyelesaian proyek, dan menyerahkan bukti pembayaran proyek atas penyelesaian pembayaran kepada pelanggan.

Kelemahan Sistem Informasi Akuntansi pada CV Satria Computindo.

Dalam penelitian ini, sistem informasi akuntansi yang sedang berjalan didokumentansikan dengan menggunakan bagan alir data (flowchart). Dari bagan alir yang telah dibuat ditemukan beberapa kelemahan-kelemahan sistem informasi akuntansi yang berjalan saat ini yaitu: pencatatan semua transaksi yang masih dilakukan secara manual sehingga sering terjadi salah catat, pencatatan ganda, lupa catat, yang diakibatkan oleh human error; keterbatasan dalam mendapatkan informasi tentang persediaan secara real time, karena penghitungan persediaan masih dilakukan secara acak atau hanya ketika 
barang terlihat berkurang stoknya; Terkendalanya perolehan informasi keuangan perusahaan oleh pemilik usaha karena pencatatan masih manual, dan hanya menggunakan buku catatan sebagai media pembukuan sehingga laporan keuangan yang dihasilkan belum terstandarisasi.

\section{Rekomendasi atas Kelemahan Flowchart Sistem Informasi Akuntansi pada CV. Satria Computindo.}

Berdasarkan kelemahan-kelemahan yang telah diuraikan sebelumnya, maka peneliti memberikan rekomendasirekomendasi atas masalah tersebut yaitu: mengganti sistem pencatatan manual dengan sistem yang baru berbasis komputer dengan menggunakan Microsoft Access 2010 yang dikembangkan sesuai dengan kebutuhan usaha. Sistem berbasis komputer ini akan membantu dalam pencatatan transaksi yang lebih akurat sehingga dapat mengurangi kesalahan yang diakibatkan oleh human error; Membuat kartu stok untuk mempermudah pengecekan barang, sehingga informasi tentang persediaan barang dapat secara mudah didapatkan; Mengembangkan aplikasi laporan keuangan berbasis database dengan SAK EMKM sebagai dasarnya menggunakan Microsoft Access 2010 yang hasil output dari aplikasi ini adalah laporan keuangan yang sesuai dengan SAK EMKM agar pemilik usaha dapat memperoleh informasi untuk pengajuan kredit, pengambilan keputusan, sebagai bahan evaluasi untuk tahun-tahun berikutnya, dan lainnya.

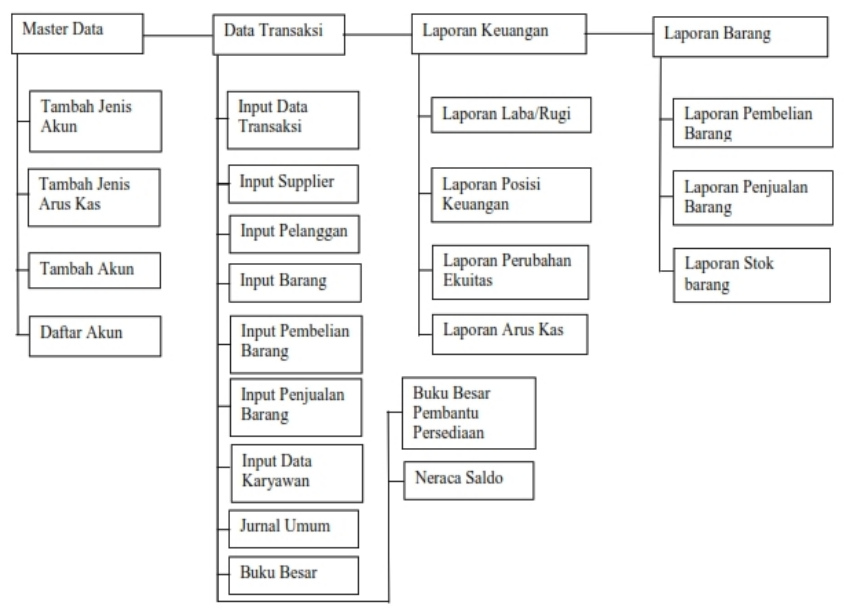

Gambar 11. Rancang Menu Aplikasi

Desain Sistem Informasi Akuntansi Berbasis Komputer untuk Penyusunan Laporan Keuangan Menggunakan Microsoft Access 2010.
Microsoft Access 2010 merupakan jawaban atas masalah yang ditemukan pada penggunaan sistem informasi akuntansi manual saat ini. Tujuan akhir dari pembuatan aplikasi ini adalah untuk mempermudah pengorganisasian laporan keuangan secara umum dari mulai input data transaksi, penjurnalan hingga akhirnya nanti menghasilkan laporan keuangan. Rancangan menu aplikasi pada Gambar 11, ditujukan untuk membuat aplikasi kebih mudah dipahami.

Desain aplikasi ini meliputi perancangan tabel sebagai tempat penyimpanan database, perancangan query sebagai pengelompokan data-data dengan sumber tabel yang sduah ada sehingga data-data tertentu sajanyang dimunculkan sesuai dengan kebutuhan, perncangan form sebagai tempat input data pada tabel, menampilkan, mencari, mengubah dan memproses data, dan perancangan report sebagai keluaran data dalam bentuk print-out data yang telah diolah.

\section{Simpulan}

Berdasarkan penelitian yang telah dilakukan, maka dapat disimpulkan bahwa CV. Satria Computindo merupakan perusahaan campuran antara perusahaan jasa dan perusahaan dagang yang melayani instalasi, upgrade dan maintenance jaringan; instalasi dan upgrade CCTV, nstalasi, upgrade dan maintenance hardware komputer; dan penjualan perangkat dan suku cadang piranti komputer. Dalam menjalankan aktivitas usahanya telah menggunakan sistem informasi akuntansi; dan Desain sistem informasi akuntansi berbasis komputer menggunakan Microsoft Access 2010 untuk pembuatan laporan keuangan, meliputi perancangan tabel, pembuatan relasi antar tabel, perancangan query, perancangan form, dan perancangan report.

\section{Referensi}

Ikatan Akuntan Indonesia (IAI). 2017. Exposure Draft Standar Akuntansi Keuangan Entitas Mikro, Kecil, dan Menengah (ED-SAK EMKM). Dewan Standar Akuntansi Keuangan, Jakarta.

Indriantoro, Bambang S. 2014. Metodologi Penelitian Bisnis. Edisi Pertama. BPFE-Yogyakarta, Yogyakarta.

Miles, M. B. \& Huberman, A. M. 1992. Analisis Data Kualitatif: Buku Sumber Tentang Metode Baru. UI Press, Jakarta.

Romney, Marshall B., Steinbart, Paul J. 2012. Accounting Information Systems. Twelfth Edition. Global Edition, Pearson Education Limited.

Sugiyono, 2012. Metode Penelitian Kuantitatif, Kualitatif dan R\&D. Alfabeta. Bandung.

Widodo, Ahmad Bayu. 2014. Perancangan Basis Data Akuntansi Berbasis Microsoft Access untuk Mendukung Sistem Informasi Akuntansi pada Pembukuan dan Pelaporan Keuangan Entitas Usaha Mikro Kecil dan Menengah (UMKM). Fakultas Ekonomika dan Bisnis. Universitas Gadjah Mada.. 